\title{
Review on Role of Biochar Amendment in Nitrate Leaching
}

\author{
A.K. Kanthle ${ }^{1,2 *}$, K. Tedia ${ }^{2}$ and N.K. Lenka ${ }^{3}$ \\ ${ }^{1}$ Department of Agriculture Development, Farmer Welfare and Bio Technology, \\ Government of Chhattisgarh, Mungeli, India \\ ${ }^{2}$ Indira Gandhi Krishi Viswa Vidyalaya, Raipur, India \\ ${ }^{3}$ Indian Institute of Soil Science, Nabibagh, Bhopal, India \\ *Corresponding author
}

\section{Keywords}

Biochar, Nitrate leaching, Carbon, Sequestration, Soil fertility

\section{Article Info}

Accepted:

10 November 2019

Available Online:

10 December 2019
The application of biochar to soil is a recent approach to establish a significant, long-term, sink for atmospheric carbon dioxide in terrestrial ecosystems. Biochar is a soil and sediment component prepared by pyrolysis. Their compositions vary by pyrogenic organic materials ranging from slightly charred biomass to charcoal. It is a good soil amendment that increases water holding capacity of soil; increase soil fertility, increased crop production, reducing emissions and increasing the sequestration of atmospheric $\mathrm{CO}_{2}$ into soils, strong sorption's affinity for organic contaminant and mostly control pollutant migration such as reduce nitrate leaching from soil. Nitrate leaching from agricultural soils is a major concern to the groundwater, surface water bodies, and environment and also affects the farmers 'economy. Biochar is anticipated to be an effective mitigation option to nitrate leaching.

\section{Introduction}

Nitrate leaching is one of the common concerns reported from intensive agriculture areas. The problem is severe in areas depending heavily on added soil nutrients in form of chemical fertilizers with low supplementation of organic inputs. Because of the less clay content and dominance of less activity clays with low surface areas, coarse- and medium-textured soils are prone to nitrate leaching. However, with regular addition of chemical fertilizers and declining soil organic carbon (SOC) content, even clay soils may contribute to nitrate leaching beyond the root zone.

Apart from the role of soil texture, the SOC content has a vital role in regulating nitrate leaching. The SOC content is a function of 
soil properties and soil management. In intensive agriculture systems, poor SOC management in form of low supplementation of organics is the primary reason for reducing soil quality. Of late, biochar has been used as an amendment to improve soil quality and reduce leaching loss of nutrients (Laird et al., 2010; Mukherjee et al., 2014). Biochar application to soil increases the overall sorption capacity, and thus, may influence the soil function to retain nutrients and filter harmful chemicals.

Use of biochar as a potential soil amendment has recently generated interest among researchers (Laird et al., 2010; Kanthle et al., 2016). Among a host of benefits, biochar is known to mitigate leaching loss of $\mathrm{NO}_{3}{ }^{-}$ions (Kanthle et al., 2016) and improve $\mathrm{N}$ uptake. Biochar is a solid and recalcitrant carbon rich product derived from the pyrolysis of biomass residues in oxygen limited environment at a relatively low temperature $\left(<700{ }^{\circ} \mathrm{C}\right)$ (Mukherjee et al., 2014). Biochar application is believed to modify the soil environment through increase in the cation exchange capacity, higher surface area, enhanced water retention, modification in the soil $\mathrm{pH}$, influencing the microbial activity and by enhancing the fine root biomass (Glaser et al., 2002).

As the benefits of biochar application mostly accrue from altered ion exchange capacity and surface charge density, it is likely that land use and consequently soil organic matter (SOM) content to be a major factor in regulating the efficiency of biochar in mitigating nitrate leaching.

Previous studies assessing the impact of biochar on nitrate leaching has mostly concentrated on the level of biochar, type of biochar material and on added manures (Laird et al., 2010; Singh et al., 2010; Mukherjee and Zimmerman, 2013).
Effect of biochar and other soil amendments on nitrate leaching

Biochar is a carbonaceous product (black carbon) formed by thermal decomposition of an organic material under limited supplies of oxygen and at relatively low temperature ( $<$ $700{ }^{\circ} \mathrm{C}$ ). It is a potential mitigation tool to reduce $\mathrm{NO}_{3}{ }^{-}$leaching (Lehmann and Joseph, 2009). Addition of biochar to soil helps in improving soil quality by improving water and nutrient retention (Glaser et al., 2002). Biochar has the ability to retain nitrogen $(\mathrm{N})$ within a soil due to it being able to enhance ammonia $\left(\mathrm{NH}_{3}\right)$, ammonium $\left(\mathrm{NH}_{4}{ }^{+}\right)$and $\mathrm{NO}_{3}{ }^{-}$ adsorption (Steiner et al., 2008; Singh et al., 2010), thus making these $\mathrm{N}$ sources unavailable for nitrification or $\mathrm{NO}_{3}{ }^{-}$leaching. Biochar has been proposed as a key tool to improve soil health and retain plant available soil nutrients from different losses and climate change mitigation because of its potential for an immediate increase in soil carbon (C) storage beyond normal limits due to its stability. Benefits of biochar may also result from its physical structure and chemical composition: soil moisture and solute retention; sorption or stabilization of nutrient ions. Thus biochar properties are likely to impact on the complex interactions between soil, plants and microbes. Several amendments including solid manures, simple sugars such as glucose, glycerol and other carbonaceous materials have been tested to reduce nitrate leaching in agricultural soils. Ritz and Griffiths (1987) observed that amendments with glucose significantly reduced the amount of nitrate leaching from a sandy soil amended with nitrate. Tolner et al., (2012) studied an alternative way to prevent nitrate leaching in sandy soil by using glycerol as a biodiesel byproduct. They reported that nitrate leaching can be significantly decreased by using glycerol treatment. Glycerol represents an easily accessible source of energy for microbes in soil. 
There are a number of studies available on biochar amendment particularly from the western countries. Burgos et al., (2006) conducted a one year column $(19 \mathrm{~cm}$ diameter and $60 \mathrm{~cm}$ height) experiment to estimate the nitrate losses from the soil amended with three organic materials, a municipal solid waste compost (MWC), a non-composted paper mill sludge (PS), and an agro forest compost (AC). Amendments were mixed with the top soil (0$15 \mathrm{~cm})$ at a rate equivalent to $50000 \mathrm{~kg} \mathrm{ha}^{-1}$. The columns were periodically irrigated simulating rainfall in the area of study, receiving in total $415 \mathrm{~mm}$ of water, and the water draining was collected during the experimental period and analyzed for $\mathrm{NO}_{3}{ }^{-} \mathrm{N}$. At the end of the experimental period $\mathrm{NO}_{3}{ }^{-} \mathrm{N}$ content in soil columns at three depths (0-20, 20-35 and $35-50 \mathrm{~cm}$ ) was determined. Result showed that nitrate leaching was higher in soil treated with municipal solid waste compost (MWC), due to its higher N-mineralization rate compared to non-composted paper mill sludge (PS), and agro forest compost (AC).

Laird et al., (2010) in a laboratory column study used biochar as an amendment with treatments containing $0,5,10$, and $20 \mathrm{~g}$ biochar kg $\mathrm{kg}^{-1}$ soil, with and without $5 \mathrm{~g} \mathrm{~kg}^{-1}$ of dried swine manure. Leaching events were sampled weekly for 45 weeks. Measurements showed a significant decrease in the total amount of $\mathrm{N}, \mathrm{P}, \mathrm{Mg}$, and $\mathrm{Si}$ that leached from the manure-amended columns as biochar rates increased, even though the biochar itself added substantial amounts of these nutrients to the columns. Among columns receiving manure, the $20 \mathrm{~g} \mathrm{~kg}^{-1}$ biochar treatments reduced total $\mathrm{N}$ and total dissolved $\mathrm{P}$ leaching by $11 \%$ and $69 \%$, respectively. These laboratory results indicate that addition of biochar to a typical mid-western agricultural soil substantially reduced nutrient leaching, and suggested that biochar additions to soil could be an effective management option for reducing nutrient leaching in production agriculture.
Singh et al., (2010) studied to assessed the influence of four biochars (wood and poultry manure biochars synthesized at $400{ }^{\circ} \mathrm{C}$, nonactivated, and at $550{ }^{\circ} \mathrm{C}$, activated, abbreviated as: W400, PM400, W550, PM550, respectively) on nitrous oxide $\left(\mathrm{N}_{2} \mathrm{O}\right)$ emission and $\mathrm{N}$ leaching from an Alfisol and a Vertisol. They concluded that in the first leaching event, higher nitrate leaching occurred from the PM400-amended soils compared with the other treatments. In the second event, the leaching of ammonium was reduced by 55 to $93 \%$ from the W550- and PM550-Alfisol and Vertisol, and by 87 to $94 \%$ from the W400- and PM400-Vertisol only. Increased effectiveness of biochar in reducing ammonium leaching over time was due to increased sorption capacity of biochars through oxidative reactions on the biochar surfaces with ageing.

Knowles et al., (2011) in a lysimeter experiment in two silt loam soils used biochar (102 t/ha equivalent) and biosolids (600 and $1200 \mathrm{~kg} \mathrm{~N} / \mathrm{ha}$ equivalent) to study whether biochar, a form of charcoal that is added to soil, could reduce nitrate leaching from biosolids amended soil. The data from 5 months of leachate sampling showed nitrate leaching from biochar plus biosolid amended soils is less $(4.1 \%)$ compared to the control treatments $(7.1 \%)$.

Kameyama et al., (2012) evaluated the effects of sugarcane bagasse charcoal on nitrate leaching in a Shimajiri Maji soil with low water- and fertilizer-retaining capacity. The results showed that sugarcane bagasse biochar produced at $800{ }^{\circ} \mathrm{C}$ was able to reduce the leaching of nitrate from a calcaric dark red soil by $5 \%$ when applied at a rate of $10 \%(\mathrm{w} / \mathrm{w})$. They attributed this reduction in leaching to mainly physical adsorption of the nitrate and water by the micro porous biochar.

Soil biochar addition can significantly decrease short-term nitrate leaching as 
reported by Ventura et al., (2012) in a lysimetric study in Italy. They conducted an experiment to evaluate the effect of biochar addition on short-term $\mathrm{N}$ leaching in a mature apple orchard growing on sub-alkaline soils. Cumulative nitrate $\left(\mathrm{NO}_{3}{ }^{-}\right)$and ammonium $\left(\mathrm{NH}_{4}{ }^{+}\right)$leaching was measured in treated and control plots 4 months after the addition of biochar and the following year by using ionexchange resin lysimeters installed below the plowed soil layer. The study showed that cumulative $\mathrm{NO}_{3}{ }^{-}$leaching was not affected by biochar after 4 months, whereas in the following year it was significantly $(p<0.05)$ reduced by $75 \%$ over the control (from 5.5 to $1.4 \mathrm{~kg} \mathrm{ha}^{-1}$ ). Conversely, $\mathrm{NH}_{4}^{+}$leaching was very low and unaffected by soil biochar treatment.

Zhang et al., (2013) monitored changes in dynamics of soil nitrate accumulation due to biochar application at rates $\left(\mathrm{kg} \mathrm{ha}^{-1}\right)$ of $0\left(\mathrm{C}_{\mathrm{K}}\right)$, $2250\left(\mathrm{C}_{1}\right)$, and $4500\left(\mathrm{C}_{2}\right)$ for each of the two crop seasons in 2007. A treatment with $750 \mathrm{~kg}$ biochar-based fertilizer ha ${ }^{-1}\left(C_{N}\right)$ for each of two crop seasons was also included. Biochar tended to increase the soil cation exchange capacity (CEC) in the $0-20 \mathrm{~cm}$ soil layer and nitrate retention in the $1.0 \mathrm{~m}$ soil profile, but there was no significant difference between biochar treatments and $\mathrm{C}_{\mathrm{K}}$. Grain yield of $\mathrm{C}_{1}$, $\mathrm{C}_{2}$, and $\mathrm{C}_{\mathrm{N}}$ was improved by $10.3 \%, 16.9 \%$, and $15.5 \%$ compared with $\mathrm{C}_{\mathrm{K}}$, respectively, but only $\mathrm{C}_{2}$ was significantly different from CK. Irshad et al., (2014) in a study in a sandy soil compared the efficacy of different amendments such as charcoal, manure, sawdust and wood ash with application of urea at the rate of $300 \mathrm{~kg} \mathrm{~N}^{-1}$. Nitrate was determined during six leaching events. Results indicated that urea application increased nitrate $\left(\mathrm{NO}_{3}{ }^{-}\right)$concentration in leachate. Soil amendments substantially reduced $\mathrm{NO}_{3}{ }^{-}$in leachates irrespective of the type of material used. The efficacy of amendments to reduce $\mathrm{NO}_{3}{ }^{-}$leaching was in the order of charcoal < wood ash < saw dust < manure. Mukherjee et $a l$. , (2014) compared the reclaimation efficacy of three soil amendments, viz. humic acid, water residual treatment and biochar on leaching of nutrients in a silty loam soil in USA. Biochar-amended soil reduced mean cumulative leaching of TOC by $30 \%$, nitrate by $33 \%$, and nitrite by $34 \%$, compared to the control (control: 93, 75, and $2 \mathrm{mg} \mathrm{kg}^{-1}$ of TOC, nitrate, and nitrite, respectively), likely due to sorption by the biochar.

Sika and Hardie (2014) conducted an experiment to determine the potential of pine wood biochar to reduce leaching of ammonium nitrate fertilizer $\left(100 \mathrm{~kg} \mathrm{~N} \mathrm{ha}^{-1}\right)$ from a sandy soil in South Africa and to quantify the exchangeable inorganic $\mathrm{N}$ (2 M $\mathrm{KCl})$ remaining after intensive leaching. Laboratory columns containing sandy soil and biochar $(0,0.5,2.5$ and $10.0 \% \mathrm{w} / \mathrm{w})$ were leached weekly over a period of six weeks simulating heavy winter rainfall. They concluded that biochar $(0.5,2.5$ and $10.0 \%$ $\mathrm{w} / \mathrm{w})$ significantly reduced the cumulative amount of ammonium (12, 50 and $86 \%$, respectively) and nitrate (26, 42 and 96\%, respectively) leached relative to the control soil.

\section{References}

Burgos P, Madejon E, Cabrera F. (2006). Nitrogen mineralization and nitrate leaching of a sandy soil amended with different organic wastes, Waste Manag. Res., 24(2): 175-182.

Glaser B, Lehmann J, Zech W. (2002). Ameliorating physical and chemical properties of highly weathered soils in the tropics with charcoal-a review, Biol. Fert. Soils 35: 219-230.

Irshad M, Waseem A, Umar M, Sab MA. (2014). Leach ability of Nitrate from Sandy Soil Using Waste Amendments, Communication in Soil and Plant 
Analysis, 45(5): 680-687.

Kameyama K. Miyamoto T, Shino T, Shinogi Y. (2012). Influence of sugarcane bagasse-derived biochar application on nitrate leaching in calcaric dark red soil, Journal of Environmental Quality, 41 (4): 1131-1137.

Kanthle AK, Lenka NK, Lenka S, Tedia K. (2016). Biochar impact on nitrate leaching as influenced by native soil organic carbon in an Inceptisol of central India, Soil \& Tillage Research 157 (2016) 65-72.

Knowles OA, Robinson BH, Contangelo A, Clucas L. (2011). Biochar for the Mitigation of nitrate leaching from soil amended with biosolids, Science of the Total Environment, 409: 3206-3210.

Laird D, Fleming P, Wang B, Horton R, Karlen D. (2010). Biochar impact on nutrient leaching from a Midwestern agricultural soil, Geoderma, 158: 436442.

Lehmann J, Joseph S. (2009). Biochar for environmental management: an introduction. In: Lehmann J, Joseph S. ed. Biochar for environmental management, science and technology. London, Earthscan, 1-12.

Mukherjee A, Lal R, Zimmerman AR. (2014). Impacts of Biochar and Other Amendments on Soil-Carbon and Nitrogen Stability: A Laboratory Column study, Soil Sci. Soc. Am. J., doi: 10.2136/sssaj2014.01.0025.

Mukherjee A. Zimmerman AR. (2013). Organic carbon and nutrient release from a range of laboratory-produced biochars and biochar-soil mixtures,
Geoderma, 193-194: 122-130.

Ritz K, Griffiths BS. (1987). Effects of carbon and nitrate addition to soil upon leaching of nitrate, microbial predators and nitrogen uptake by plants, Plant and Soil, 102(1987): 229-237.

Sika MP, Hardie AG. (2014). Effect of pine wood biochar on ammonium nitrate leaching and availability in a South African sandy soil, European Journal of Soil Science, 65: 113-119.

Singh BP, Hatton BJ, Singh B, Cowie AL, Kathuria A. (2010). Influence of biochars on nitrous oxide emission and nitrogen leaching from two contrasting soils, J Environ Qual., 39: 1224-1235.

Steiner C, Glaser B, Teixeira WG, Lehmann J, Blum W, Zech W. (2008). Nitrogen retention and plant uptake on a highly weathered central Amazonian Ferralso amended with compost and charcoal, J. Plant Nutri. Soil Sci., 171: 893-899.

Tolner L, Rethati G, Kovacs A. (2012). Examination of an alternative way to prevent nitrate leaching in soil by using glycerol as a biodiesel by product, Novenyterm, 61(2012): Suppl. 3.

Ventura M, Sorrenti G, Panzacchi P, George E, Tonon G. (2012). Biochar Reduces Short-Term Nitrate Leaching from A Horizon in an Apple Orchard. Journal of Environmental Quality, 42(1): 7682.

Zhang Q Z, Wang XH, Du ZL, Liu X R, Wang YD. (2013). Impact of biochar on nitrate accumulation in an alkaline soil, Soil Research, 51 (6): 521-528.

\section{How to cite this article:}

Kanthle, A. K., K. Tedia and Lenka, N. K. 2019. Review on Role of Biochar Amendment in Nitrate Leaching. Int.J.Curr.Microbiol.App.Sci. 8(12): 826-830.

doi: https://doi.org/10.20546/ijcmas.2019.812.106 